Primljeno: 2/12/2019

UDK: 373(497.571):821.163.42-93 Car Emin, Viktor

Izvorni znanstveni rad

\title{
O HRVATSKOME ŠKOLSTVU U ISTRI KROZ ČASOPISNE PRINOSE VIKTORA CARA EMINA ${ }^{1}$
}

\author{
Vjekoslava Jurdana \\ Fakultet za odgojne i obrazovne znanosti \\ Sveučilište Jurja Dobrile u Puli \\ vjurdana@unipu.hr \\ Mariela Tomičić \\ Fakultet za odgojne i obrazovne znanosti \\ Sveučilište Jurja Dobrile u Puli
}

1 Rad je dio međuinstitucijskoga znanstvenoistraživačkog projekta Viktor Car Emin i njegova uloga u razvoju hrvatskog školstva i dječje književnosti u Istri (Centar za istraživanje dječje književnosti i kulture Učiteljskoga fakulteta Sveučilišta u Zagrebu i Fakultet za odgojne i obrazovne znanosti Sveučilišta Jurja Dobrile u Puli). 


\section{SAŽETAK}

Književno stvaralaštvo Viktora Cara Emina (1870. - 1963.) opsežno je i raznoliko, a uključuje tekstove i djela pisana za djecu. U ovome se radu prikazuju odabrani Carevi tekstovi i to iz dva hrvatska dječja časopisa u Istri koja je Car pokrenuo i uređivao. Zbog ograničenosti opsega rada ovdje su prikazana i analizirana (samo) dva Careva teksta kao odabrani primjeri koji eksplicitno i slikovito prikazuju problematiku hrvatskoga školstva u Istri. Analiza pokazuje da je Carevo stvaralaštvo za djecu uvelike produkt onodobne političke situacije u Istri. Carev se prinos u časopisima pokazuje kao patriotsko-sentimentalan, didaktičan i nacionalno-politički prigodan. U prvome planu nije ostvarenje književnoumjetničke vrijednosti, već politička i aktivistička uloga nacionalnoga osvješćivanja. Carevi tekstovi o školstvu dio su političke borbe za razvoj hrvatskoga školstva u Istri, ali i autorovo obraćanje mladim čitateljima u njihovu vremenu i prostoru.

Ključne riječi: Viktor Car Emin, dječja književnost, školstvo, hrvatski narodni preporod u Istri, dječji časopis 


\section{UVOD}

Književno stvaralaštvo Viktora Cara Emina (1870. - 1963.) opsežno je i raznoliko, a kao pripadnik druge generacije istarskih preporoditelja veći dio svoga opusa objavljuje u jeku hrvatskoga narodnog preporoda $u$ Istri $^{2}$, a shodno tome posvećuje većinu svojih djela. ${ }^{3}$

U tome okviru valja sagledati i njegovo stvaralaštvo za djecu koje je zapravo neistraženo jer je objavljivano u onodobnim časopisima, a samim time je i teže dostupno. Iako je Car jedan od najplodnijih pisaca za djecu, hrvatska je javnost na njegovu dječju književnost zaboravila. Ines Srdoč-Konestra to potvrđuje: „U tako specifičnim prilikama obiman je Carev književni opus često ostajao izvan relevantnih povijesti hrvatske književnosti“ (Srdoč-Konestra, 2000, 407). ${ }^{4}$

Cilj je ovoga rada prikazati dio istražene izvorne građe o Carevu stvaralaštvu za djecu, i to iz dva hrvatska dječja časopisa u Istri koja je Car pokrenuo i uređivao. U tome su okviru izabrana dva teksta koja omogućuju analitički uvid u Carevu (po)etiku pri tematiziranju problematike hrvatskoga školstva u Istri, a kojima se obraća i mladim čitateljima.

2 Hrvatski narodni preporod u Istri nacionalni je pokret istarskih Hrvata od 60-ih godina 19. stoljeća do početka 20. stoljeća. To razdoblje smatra se središnjom ili odlučnom fazom integracije suvremene hrvatske nacije u Istri. Prije toga, već od 30-ih godina 19. stoljeća, u početnome razdoblju, prodiru ideje ilirizma i stvaraju se temelji za smišljeni rad na ostvarivanju nacionalnih ciljeva. No, središnja faza obilježena je institucionalnim i sustavnim širenjem nacionalne svijesti. Nositelji hrvatskoga nacionalnointegracijskoga programa razlikuju se generacijski i po političkome programu. Prva generacija (narodnjačka), koju su predvodili Juraj Dobrila, Dinko Vitezić i Matko Baštijan, vodila je pokret u duhu južnoslavenske ideologije đakovačkoga biskupa Josipa Jurja Strossmayera i zanosila se idejom ujedinjenja svih Južnih Slavena. Od 80-ih godina 19. stoljeća nastupa druga generacija preporoditelja (pravaška), predvođena Matkom Laginjom, Vjekoslavom Spinčićem i Matkom Mandićem, koja je slijedila pravašku ideologiju Ante Starčevića, ali uz neke prilagodbe istarskim prilikama. (Cetnarowicz, 2014, 63-65.) Ta tri nova imena, obilježila su narodni nacionalni pokret istarskih Hrvata tijekom sljedećih desetljeća, a Viktor Car Emin je u tome razdoblju nacionalne borbe istarskih Hrvata, u vrijeme sukoba s talijanašima, talijanskim iredentizmom pokazao snažno rodoljublje koje dobiva izrazito političko obilježje. Angažirajući se aktivno, razvio je široku društvenu djelatnost te je postao blizak suradnik već spomenutih D. Vitezića, M. Laginje, V. Spinčića i M. Mandića.

3 O književnome životu u Istri tijekom naznačenoga razdoblja valja naznačiti: „U okviru književne povijesti, preporodna se epoha u Istri može pratiti u više razvojnih faza - od prvih pretpreporodnih te zatim preporodnih pojava od početka 19. stoljeća do 1870 . godine, tj. do pojave lista Naša sloga; sljedeća tri desetljeća, kao druga faza, mogu se imenovati kao doba Naše sloge, s najuočljivijim značajkama koje možemo svrstati pod zajednički pojam preporodne književnosti; nakon 1900. god. nastupa završni period te epohe, kada literarna ostvarenja počinju postupno gubiti najizrazitija obilježja preporodnog angažmana, a istarski se pisci sve više nastoje uklopiti u opće tokove matične hrvatske literature, u odnosu na koju se do tada istarski književni krug razvijao donekle izdvojeno i u razvojnoj asinkroniji.“ (Strčić, 1994:14)

4 Autorica je istakla $(2008,9)$ kako je upravo taj segment, naime Careva književnost za djecu, također opsežan, i uključuje uz autorske tekstove i mnoge prerade i prijevode. Stoga taj dio Careva opusa treba obraditi u zasebnom znanstvenom i stručnom istraživanju i radu. 


\section{O ŠKOLI I UČITELJSTVU U GAREVU ŽIVOTU}

Viktor Car rođen je u Kraju (pored Lovrana), a kao dječak, školske dane provodi u Lovranu kod bake gdje su ga poslali roditelji s obzirom na to da u Kraju nije bilo škole. Ondje, od 1876. do 1880. godine polazi talijansku osnovnu školu. U svojoj autobiografiji (Car Emin, 1981) navodi kako mu Lovran nije ostao u najboljem sjećanju zbog ruganja vršnjaka. ${ }^{5}$ Posebnu je ulogu u lošem sjećanju imao njegov talijanski učitelj, „ljutiti narodni otpadnik“ (Car Emin, 1981, 588). Tada se Car po prvi put susreće s odnarođivanjem, problemom kojemu će se suprotstavljati čitav svoj život pomoću pera i tinte. Od 1880. do 1881. godine pohađao je u Rijeci jedan razred mađarske gimnazije. Dolazak u riječku sredinu ponovno je za istarskoga dječaka značio bolno odvajanje od zavičaja. Grad u kojem su tada dominirali talijanski i mađarski jezik bio je za nj oličenjem odnarođene nacionalne sredine (Lukežić, 2016, 17).

Na nagovor mošćeničkoga župnika, ,čeličnog Hrvata“ 1885. godine Car odlazi u Kopar kako bi polazio Državnu učiteljsku školu. Kasnije je zapisao kako je to bila: „Velika, mogu reći, presudna prekretnica u mom tada još mladom životu!“ (Car Emin, 1981, 592). Profesor hrvatskoga jezika bio mu je Fran Franković, nazvan „ocem hrvatskih učitelja u Istri“ (Lukežić, 2016, 21). Franković je Cara upoznao s mnogim djelima i likovima hrvatskih pisaca te ga poticao na pisanje i objavljivanje vlastitih tekstova na hrvatskome jeziku. Također mu je mnogo govorio o najistaknutijim istarskim vođama hrvatskoga preporoda koje je osobno poznavao.

Od 1889. do 1900. godine Car je kao učitelj radio na pučkim školama u Sovinjaku pored Buzeta, Lipi i Voloskom. Godine 1895. postaje tajnikom Družbe Sv. Ćirila i Metoda za Istru, ponajprije u tajnosti, a zatim od 1900. godine započinje javno obavljati tu funkciju na kojoj je ostao sve do 1921. godine.

5 „Malko mi je smetala ona njihova naduvenost i bahatost, ona drska samosvijest gradske djece što su je u momentima kad bih im naprkosio, pokazivali i prema meni, malom seljančetu iz Kraja, gdje - kako su rugajući mi se govorili - rastu sami hrastovi - „grmićí. U takvim trenucima ja sam za njih bio što i svako dijete iz sela: 'coban'. Lovranci su 'cakavci',a cakavac sam i ja. Tko da opiše moju kasniju muku s onim dijakritičkim znacima što smo ih mi zvali 'rožićima' i što su mi uvijek izmicali iz pera!“ (Car Emin, 1981, 588-589). 


\section{DRUŽBA SV. ĆIRILA I METODA ZA ISTRU I VIKTOR GAR EMIN}

Tijekom hrvatskoga narodnog preporoda u Istri kao dijelu nacionalno integracijskih procesa (druga polovica 19. st. i prva polovica 20. st.) ${ }^{6}$ jedan od najvažnijih oblika borbe za opstanak hrvatskoga bića pod vlašću tuđina bio je razvoj hrvatskoga školstva. Štoviše, borba za hrvatske škole u Istri bila je glavno obilježje cjelokupne borbe istarskih Hrvata za svoje nacionalno i kulturno održanje (Demarin, 1978, 7). Naime, „borba za školstvo bio je jedino najvidniji izraz suprotnosti između Hrvata i klase, koja je dotad, na osnovi svoje ekonomske snage, bila jača i društvena i politička snaga. Iako je još 1848. godine brojčani odnos između Talijana i Slavena (Hrvata i Slovenaca) u Istri bio približno u omjeru 1:3 (134.355 Hrvata, 31.995 Slovenaca, 60.040 Talijana), nitko nije Talijanima osporavao vlast. “ (Peruško, 1953, 120) U tim okolnostima, ističe Peruško $(1953,122)$ „nastavni jezik u školi određivalo je Zemaljsko (pokrajinsko) školsko vijeće pa je to vijeće i u školama sa hrvatskim nastavnim jezikom određivalo kao obavezan jezik talijanski ili njemački (1884.-1885. školske godine, u 34 hrvatske škole obavezan talijanski, a u 36 njemački), dok se niti u jednoj talijanskoj školi nije učilo hrvatski ili slovenski jezik kao obavezan predmet." Nametnuti talijanski jezik kao službeni jezik u Istri značio je favoriziranje talijanske narodne manjine na štetu hrvatske narodne većine. Osnovne škole postojale su u gradovima, a postupno sve više i u većim mjestima. U gradskim se osnovnim školama cjelokupna nastava izvodila na talijanskome jeziku. Postojale su i dvojezične škole: talijansko-hrvatske. To su bile javne škole, ali su ondje hrvatski učitelji radili u veoma nepovoljnim okolnostima s favoriziranjem talijanskoga jezika i talijanskih učitelja. „LEGA NAZIONALE“, talijanska udruga čija je zadaća bila otvarati osnovne škole i dječje vrtiće s talijanskim nastavnim jezikom i talijanskim odgojnim duhom ${ }^{7}$, gradila je talijansku

6 Riječ je o vremenskome okviru složenih nacionalno integracijskih procesa na tlu Istre, razdoblju sukoba, netolerancije, nerazumijevanja u tijeku žilave borbe triju naroda (Hrvata, Slovenaca i Talijana) za vlastito pravo na samoodređenje i vlastitu državu. Pri tome je hrvatska nacionalna integracijska i državotvorna misao istarskih Hrvata izgrađivana kao dio jedinstvenoga hrvatskoga procesa pri čemu je moguće uočiti tri veće cjeline. Jedna zahvaća razdoblje od početka 19. stoljeća do godine 1918., druga od godine 1918. do 1945. godine, i treća od 1945. do 1990. godine (Šetić, 2005, 133).

7 Talijani su najprije, 1886. godine u Trstu, osnovali društvo „Pro Patria“. Njegova zadaća je bila da putem svojih podružnica u Goriškoj, Istri i Dalmaciji otvara osnovne škole i dječje vrtiće s talijanskim nastavnim jezikom i talijanskim odgojnim duhom, da pronalazi donatore tih ustanova i da organizira dobrotvorne zabave u njihovu korist. Aktivisti „Pro Patrie“ otvoreno su zagovarali da se Italiji pripoje pojedina područja iz sastava austrijske države pa je austrijsko Ministarstvo unutarnjih poslova 1890. godine zabranilo daljnji rad toga iredentističkoga društva. Nakon te zabrane talijanski su iredentisti osnovali novu udrugu „Lega Nazionale" kojom su provodili intenzivnu talijanizaciju, prije svega, osnivajući svoje pučke škole i dječja zabavišta (Šetić, 2010, 133). Najviše je pomoći dobivala iz Italije 
školu u svakome, pa i najmanjem mjestu (Radetić, 1969, 174). Škole su bile lijepe moderne zidanice, a održavala ih je, kao i njihove učitelje, sama Lega dobrovoljnim prinosima svojih članova. Djeca, koja su polazila Leginu školu dobivala su odmah besplatno sve knjige i učila, a osim toga i odjeću, obuću i hranu. S druge strane, nije bilo nikakvih mogućnosti za hrvatske škole. Vlast ih nije davala, a sam narod nije imao sredstava, nije bilo zgrada, niti novaca, a niti učitelja (Radetić, 1969, 174-175). Stoga, kako bi se razvilo hrvatsko školstvo u Istri, osnovana je u Puli 24. veljače 1893. godine „Družba sv. Ćirila i Metoda za Istru“ kao udruga za podupiranje razvoja hrvatskoga školstva u Istri.

Temeljna zadaća Družbe - otvaranje novih škola, doživjela je upravo za Careva tajništva veliki uzlet. Godišnje su u prosjeku otvarane čak četiri nove škole.

O svojoj ulozi tajnika Družbe, Car je istaknuo: „Ne znam, dali sam sa onoga mjesta dao Družbi sve ono, što bih mogao i morao, ali jedno mogu da kažem: ništa me u životu nije tako zaokupljalo, kao ova naša ustanova, i ni jednoj se nisam misli posvetio takvim zanosom, kao napretku ove naše institucije. (...) ja sam u nju gledao kao u simbol jedne velike i vrlo časne borbe za našu materinju riječ, za naše najviše narodne ideale, za naš nacionalni opstanak." (Car Emin, 1953, 38)

Svakako, u svojem poslanju Car nije zaboravio ni svoj uži zavičaj te je snažno djelovao i u svojoj Liburniji, a razdoblje od početka 20. stoljeća pa do početka Prvoga svjetskog rata donosi mnoge plodove. To je razdoblje „završni period preporodne književnosti u Istri“ a kojem „osnovni pečat daje opatijski književni krug s Carem i Katalinićem na čelu. Opatija i Volosko tada postaju jedno od glavnih žarišta preporodnih borbi: tu je sjedište prosvjetne Družbe sv. Ćirila i Metoda za Istru, ovdje izlazi vrlo angažirani Narodni list, osnovana je i Narodna zajednica, u Opatiji djeluje društvo Zora, a u Voloskom 'Narodni dom', ovamo s Lošinja prelazi Kraljićev dječji list Mladi Istranin/Mladi Hrvat, a i sportska društva nose vidljiva obilježja nacionalno-preporodnoga rada.“ (Strčić, 1984, 218).

\section{VIKTOR GAR EMIN I DJELOVANJE U ČASOPISIMA ZA DJECU}

Ponajprije, valja razjasniti nastanak hrvatske časopisne produkcije za djecu u Istri. Prvi je pokrenut časopis Mladi Istran s podnaslovom „List za mladi svijet“, i to u Malome Lošinju 15. siječnja 1906. godine, a izlazio je do 1908. godine. Njegov izdavač i utemeljitelj bio je Josip Antun Kraljić, nadučitelj malološinjske hrvatske osnovne škole koju je osnovala i uzdržavala Družba sv. Ćirila i Metoda za Istru.

od društva „Dante Alighieri“ kojemu je bio cilj podržavati i širiti talijanstvo izvan Italije (Milanović, 1973, 367). 
Štoviše, Kraljić je radio kasnije i u Družbinoj školi u Ičićima. Časopis Mladi Istran je nudio učenicima hrvatskih osnovnih škola u Istri mnogo više od onoga što su im nudile njihove školske čitanke. On je bio zbirka brojnih priloga s raznolikom tematikom u stihu i prozi, kao i članaka s popularno-publicističkim načinom izlaganja, zbirka koja budi znatiželju i zabavlja (Šetić, 2011, 252). I upravo kao "list za mladi svijet” Mladi Istran čitao se u svim istarskim hrvatskim osnovnim školama, ponajviše u osnovnim školama Družbe sv. Ćirila i Metoda za Istru (Šetić, 2011, 254). Viktor Car Emin svoje stvaralaštvo za djecu započinje upravo u časopisu Mladi Istran ${ }^{8}$.

Nakon prestanka izlaženja Mladoga Istrana, agilni članovi Družbe sv. Ćirila i Metoda za Istru uvidjeli su prazninu pa su nastojali pokrenuti novi časopis. Te se zadaće latio Viktor Car Emin, tada upravitelj Općinske škole za daljnju naobrazbu u Opatiji i, kao što smo naznačili prethodno, vrijedni tajnik Družbe. On je 1909. godine pokrenuo književni mjesečnik Mladi Istranin. List za mladi svijet. Opatija je bila mjesto njegova izlaženja. Tiskao se u opatijskoj Knjigotiskarni V. Tomičić i dr. Vlasnik i urednik bio mu je Viktor Car Emin. On objavljuje i svoje tekstove pod raznim pseudonimima kao što su Lujo Dorčić, Tončić i Barba Šime. Taj časopis izlazio je samo jedno godište (1909.). U njegovu posljednjem, 12. broju tiskana je obavijest da će časopis nadalje izlaziti pod nazivom Mladi Hrvat. Prvi broj časopisa Mladi Hrvat izišao je u siječnju 1910. godine. Imao je isto mjesto izlaženja kao i njegov prethodnik - Opatija, jednak format, istu tiskaru, istog vlasnika i odgovornoga urednika - Viktora Cara Emina. U vremenu svoga trajanja (1910. - 1914.) Mladi Hrvat je izlazio jednom mjesečno. Šetić (2011) navodi kako je razlog promjene naziva lista činjenica da se pod nazivom Istranin mogu pronaći sva tri autohtona naroda Istre u koje spadaju Hrvati, Slovenci i Talijani. Stoga su dio imena Istranin promijenili u Hrvat kako bi se dalo do znanja da je časopis namijenjen samo hrvatskoj istarskoj djeci, ali i ostaloj djeci na hrvatskim prostorima. Važno je napomenuti kako Car nije sam došao do ideje da se promijeni ime već su ga na to potaknuli čitatelji časopisa. Pod tim je, novim imenom, časopis izlazio sve do početka Prvoga svjetskog rata, odnosno do 1914. godine, kada se časopis gasi. ${ }^{9}$

8 O scenskoj igri „Đurđica“ koju je napisao u tri čina Viktor Car Emin, a objavljena je u nastavcima u časopisu Mladi Istran 1906. godine (br. 6/1906., 94.-96., br. 7-8/1906., 108.-118.), pisali smo na drugome mjestu. Riječ je radu Viktor Car Emin i hrvatska pučka škola „Družbe sv. Ćirila i Metoda za Istru“ u Ičićima. U: Franković, B.; Polić, M. Viktor Car Emin (1870. - 1963.): zbornik radova: povodom 145. obljetnice rođenja. Mošćenička Draga: Katedra Čakavskoga sabora Općine Mošćenička Draga; Brseč: Udruga Jenio Sisolski. str. 185-213.). Prinos je to osvjetljavanju Careva književnoga stvaralaštva za djecu u kontekstu činjenice da je u prikazima Careva književnoga rada zapostavljen njegov ciklus dječje književnosti, vezan u prvome redu za taj časopis (Strčíć, 1985, 100).

9 Kasnije Car pokreće i časopis Mladi Istranin (1922. - 1928.). Godine 1922. fašisti su već počeli svoju vladavinu terora u Kraljevini Italiji čiji je teritorij obuhvaćao Istru. Unatoč svim zabranama koje su 
Svakako, valja istaknuti da su Mladi Istran / Mladi Istranin / Mladi Hrvat izvrsno uređivani dječji časopisi, s velikim brojem suradnika, tada najpoznatijih pisaca za djecu, i štoviše, odigrali su veoma važnu ulogu utječući na mladi naraštaj, „na generaciju koja će u danima što su nadolazili, nacionalno osvješćivana od malih nogu, nastaviti narodnu borbu ili u samoj Istri u periodu najžešćeg međuratnog odnarođivanja, ili izvan Istre - dokazujući postojanje hrvatskog naroda u zemlji koju je talijanski fašizam svojatao bez milosti“ (Strčić, 1985, 99). Najvrjedniji suradnici lista bili su, uz Cara, Rikard Katalinić Jeretov, Vladimir Nazor i Josip Milaković.

U časopisu su se najčešće objavljivale kraće priče i poezija za djecu, poučne priče i događaji u svijetu, kako povijesni tako i suvremeni. Priče su često bile popraćene slikama, crtežima i fotografijama, a to se naročito odnosilo na poučne priče. S obzirom na to da u vrijeme kada je časopis izlazio književnost za djecu još nije doživjela svoj vrhunac u Istri, u časopisu su se često objavljivali prijevodi stranih autora. Priče su se najčešće prevodile s francuskoga, češkoga i ruskoga.

Iako se rijetko spominju uz druge hrvatske dječje časopise, Mladi Istranin i Mladi Hrvat imali su veliku ulogu u odgoju i obrazovanju istarske djece, a među njima su stekli veliku popularnost. To možemo zaključiti na temelju broja djece koja su svaki mjesec slala svoje odgovore na zagonetke, a čija imena, ako je odgovor bio točan, možemo pročitati u svakome broju časopisa. Također to možemo zaključiti i iz odgovora koje je uredništvo dobivalo na pitanja koja su postavljali djeci, primjerice na pitanje „Što biste najvolje biti u životu i zašto?“ iz Mladoga Hrvata. Djeca koja su se javljala bila su većinom iz Istre i iz škola Družbe sv. Ćirila i Metoda, no bilo je i odgovora iz Bosne (Busovača), Budve, Osijeka, Šibenika, Karlovca, sa Brača i Cresa. U nekim se brojevima časopisa moglo pročitati kako su općine plaćale pretplatu školama, kako su čitaonice nabavljale primjerke, a neki su se primjerci naručivali za inozemstvo (primjerice za Njemačku). Uredništvo je u drugome godištu Mladoga Hrvata prikupljalo novac za knjige, a mogle su se i same knjige slati. Tada bi uredništvo donacije i knjige proslijedilo ondje gdje je za njima bila najveća potreba. Usto je u svakome broju posebno napominjano kako se prikuplja novac za otvaranje Družbinih škola. U tome kontekstu Družba je većinu svojih financijskih sredstava prikupljala dobrotvornim prilozima. I čisti dobitak mnogih priredaba bio je određen za Družbu. U korist Družbe prodavali su se i

Talijani uveli vezane uz Slavene, Car i dalje objavljuje dječje tekstove na hrvatskome jeziku. To uspijeva uz pomoć Pučkoga prijatelja, hrvatskoga časopisa koji je izlazio od 1899. do 1929. godine. S radom prestaje već u drugome tjednu 1929. godine kada fašisti izdaju zabranu izdavanja knjiga i glasila na hrvatskome jeziku. U časopisu se nije potpisivao svojim imenom već pseudonimom Barba Šime koji je povremeno koristio i prije, ponajviše u prvome izdanju Mladoga Istranina, odnosno Mladoga Hrvata. U „novome“ Mladom Istraninu često je čitatelje podsjećao na Mladoga Hrvata, koji je ugašen u vihoru rata. 
cigaretni papiri, kavini surogati, sapun, laštila za cipele, a u Puli također olovke i razglednice. Osobito je "Klub ćirilo-metodskih zidara" u Zagrebu promicao doniranje za svrhu razvitka hrvatskoga školstva u Istri. U raznim gradovima Hrvatske djelovale su podružnice Družbe koje su prikupljale dobrovoljne prihode od građanstva. Od 1895. godine prodavale su se Družbine žigice s natpisom "Bog i Hrvati" ili "Zora puca bit će dana! - Narod bez škola, jest narod bez budućnosti" i ta je djelatnost donosila znatne prihode za škole koje je financirala Družba. ${ }^{10}$

Možemo zaključiti kako su časopisi uvelike pridonijeli zajednici odgajanjem i obrazovanjem istarskih Hrvata pomoću tekstova te dobrotvornim radom (otvaranje novih škola i prikupljanje sredstava za nabavku knjiga). U tome su veliku ulogu imali i tekstovi koje je u tim časopisima objavljivao Viktor Car Emin.

\section{PRIČE POSVEĆENE HRVATSKOME ŠKOLSTVU U ISTRI}

Car je većinu svojih pripovijesti posvetio školstvu u Istri i nedostatku hrvatskih škola. Svjestan te činjenice, Car kroz svoje priče u časopisima promovira (Družbine) hrvatske škole te djeci daje do znanja da su škole Lege Nazionale najveći neprijatelji Hrvata u Istri. Car je o temi školstva napisao niz tekstova od kojih je šest dostupno na mrežnim izvorima. Za ovaj rad odabrana su dva teksta kao primjeri koji eksplicitno prikazuju angažiranost Družbe sv. Ćirila i Metoda za Istru kao graditelje budućnosti za slavensko stanovništvo u Istri. Nadalje, tekstovi slikovito prikazuju onodobne (ne)prilike za hrvatsku djecu koja su, zbog nedostatka vlastitih hrvatskih škola, morala polaziti tuđinske, talijanske škole.

\section{I oni hoće da znadu}

I oni hoće da znadu prva je Careva pripovijest o tematici školstva u Mladome Istraninu. Sastavljena je od pet poglavlja: Selo bez škole, Družba dobrih, narodnih ljudi, Mali mučenik, Ubogi Tomo i Tomo plače od sreće. Pripovijest govori o izgradnji škole, od ideje za izgradnju pa sve do njezine realizacije. Glavni su junaci, kao i u svim Carevim pričama hrvatska djeca. Prvo poglavlje govori o Toni Brandiću, dječaku koji je prije živio u selu no sad se preselio u grad. Našavši se opet u selu u kratkome posjetu, Tone svojim prijateljima govori o svome školovanju u gradu. Car Tonu uvodi u priču tako što opisuje njegov izgled i držanje koje je u suprotnosti s djecom iz sela. Car nam govori kako je "na njemu sve lijepo i gospodski“ (Car-Emin, 1909, 28) dok su ostala djeca „seljački mališi““. Tonina odjeća uvelike se razlikuje od njihove - on je odjeven $\mathrm{u}$ „Modri kaputić sa zlatnim gumbima, modre

10 I „Lega Nazionale“ je, poput „Družbe“, prodavala svoje žigice (Milanović, 1973, 367). 
hlačice do koljena, crne čarape, cipele svijetle kao zrcalo, a na glavi kapa, kao što je ono nose vojnici u Puli“. Odjeća seoske djece dijametralno je suprotna njegovoj: „Odijelo - sve krpa do krpe, obuća trošna i teška (gdjekoji je i nema!) a kapa sva zgužvana, kao da je tko po njoj nogama mastio. Ama sve onako po siromašku!“ (Car-Emin, 1909, 28). Djeca tim razlikama ne pridaju pažnju. Njima je drago što je Tone tako lijepo odjeven, njihova srca ne poznaju ni zavisti ni ljubomore. Tone seosku djecu upoznaje s 'idejom škole', no sama želja za izgradnjom nije bila dovoljna. Tada se pročuo glas da je družba dobrih, narodnih ljudi odlučila u selu izgraditi školu. Car ovdje nije mislio na grupu ljudi iz sela, već na Družbu sv. Ćirila i Metoda kojima taj opis pripada. Svi su se mještani uključili u izgradnju škole doniranjem materijala ili su pomagali u izgradnji. Među njima je bio Jožić, dječak koji umire od ozljeda zadobivenih prilikom izgradnje škole. Jožiću nude lijek, no on ga odbija jer je spreman svoj život položiti za školu. Jožić kao lik idealistički postupa - nudi mu se lijek od kojega bi potpuno ozdravio, no on to odbija i odabire smrt koja se mogla izbjeći. Možemo pretpostaviti kako je Car time htio dočarati koliko je zaista važna izgradnja (hrvatske) škole, pa čak i pod cijenu smrti. No takva odluka ipak nije svojstvena dječjem svijetu. U četvrtome se poglavlju susrećemo s likom djeteta koje odgaja skrbnik talijanaš. Car je često svoje priče posvećivao djeci koja nisu bila u mogućnosti sudjelovati u narodnome osvještavanju zbog različitih prepreka, primjerice, svojih roditelja, skrbnika ili zbog siromaštva. Majhut $(2005)^{11}$ takve situacije koje problematiziraju put nekoga junaka u dječjoj književnosti objašnjava kao put koji junak mora proći kako bi razvio svoj identitet. Junaka prati nevolja za nevoljom; dječak u priči, Toma, izgubio je oba roditelja te dobiva skrbnika Talijana Faganela. Faganel u ovome slučaju predstavlja lažnog roditelja ${ }^{12}$. Nakon što dijete ostane samo, kao što je ovdje slučaj, ono je dano drugoj osobi na skrb. Tada slijedi djetetova prilagodba na sve promjene koje novi dom i novi skrbnik sa sobom nose. Kod lažnih roditelja dijete se ne uspijeva prilagoditi zbog čega je pri-

11 U interpretaciji odabranih Carevih tekstova korisnim se pokazuje primjena teorijskoga instrumentarija kojim teoretičar dječje književnosti Berislav Majhut promatra produkciju unutar opće hrvatske dječje književnosti u razdoblju u kojem je i Car stvarao. Posebice se to odnosi na motive i tematiku o djeci siromasima i siročadi (Majhut, 2005.). Pa iako Majhut ne spominje Cara, valja istaknuti da je Carevo vrlo snažno i prepoznatljivo tematsko-motivsko obilježje upravo naznačena tematika. A sve u okviru teškoga položaja hrvatskoga naroda u Istri. Naime, hrvatska djeca, kao i hrvatski živalj u Istri tijekom 19. stoljeća bili su u vrlo teškom socijalnom, ekonomskom, kulturnom i političkom položaju. Dok je talijanska manjina bila privilegirana, s jakim ekonomskim resursima i političkom moći, hrvatskoj većini nisu se dopuštali ni minimalni uvjeti za razvoj građanskoga načina života i kulture, adekvatan općem razvoju u to vrijeme. Nerazvijen, zapušten, omalovažavan, hrvatski živalj zapravo je bio zlostavljan kao siroče od tuđinskih maćehinskih vlasti. Dakle motiv siročeta u istarskome kontekstu ima jaki društveni, ekonomski i politički semantički slojeviti naboj u Carevim tekstovima.

12 Za lažne roditelje Majhut kaže: „U jednom trenutku spiralnog pada siroče nalazi privremeni dom. (...) Ubrzo će se, međutim, ispostaviti da su probuđene nade bile lažne“ (Majhut, 2005, 210). 
morano napustiti takav dom. Toma iz Careve priče dom napušta nakon što ga od fizičkoga zlostavljanja spašava starac Miljan koji sudskim putem udomljava Tomu. Miljan ima ulogu dobrotvora ${ }^{13}$, odnosno osobe koja daruje dom. Dolaskom pod Miljanovo skrbništvo Toma ipak krene u školu te on ostvaruje svoj cilj.

\section{U tudjinskoj školi}

U četvrtome godištu Mladoga Hrvata Car je objavio tekst U tudjinskoj školi. Pripovijest opisuje kroz što prolaze Tone Žukvić i Jelica Bukovićeva, dvoje seljančića, Hrvata, koji polaze talijansku školu u gradu. Oni su jedina hrvatska djeca u toj školi zbog čega su izložena poruzi učitelja i ostalih učenika. Tone polazi školu zbog svoga oca Joška. Iako je Hrvat, Joško poslušno radi sve što mu predloži Talijan Pijero. Car Joška opisuje kao „priprosto, tupoglavo čeljade“ (Car-Emin, 1912, 34). Jelicin slučaj razlikuje se od Toninog: „Jelica je pak bila sirota bez oca i majke. Živjela je u neke tetke, pralje" (Car-Emin, 1912, 34). Tetka Jelicu šalje u talijansku školu zbog gradskih dužnosnika koji su je tako uputili ${ }^{14}$. Tone i Jelica u školi imaju problema zbog nepoznavanja talijanskoga jezika te nisu u mogućnosti pratiti nastavu, niti odgovarati na učiteljeva pitanja. Druga ih djeca izbjegavaju i rugaju se njihovoj neimaštini: „Rugali se njihovim bosim nogama, trošnom odijelu, crnom kruhu“ (Car-Emin, 1912, 34). Car tim opisom odnošenja talijanske djece prema siromašnoj hrvatskoj djeci želi pokazati koliko se ona moralno razlikuju. U pripovijesti $I$ oni hoće da znadu također se spominje razlika između siromašnih i dobrostojećih, no u toj se pripovijesti radi o hrvatskoj djeci, dok se u U tudjinskoj školi radi o hrvatskoj i talijanskoj djeci. Treba uzeti u obzir da su talijanska djeca u pripovijesti gradska djeca, dok Tone i Jelica dolaze iz drukčije, seoske sredine. Razlika između sela i grada kao motiv pojavljuje se u mnogim Carevim tekstovima - seoska su djeca dobra, nevina, čista, dok su gradska djeca prikazana kao zla i bez empatije, a najčešće se radi o Talijanima. S obzirom na to da su Tone i Jelica seoska djeca, ostali ih tretiraju kao nepoželjne, što Car u jednome trenutku i naglašava: „Jednom je došla u školu neka gospodja i zamolila učitelja, da joj maloga izvadi iz klupe, gdje je sjedio Tone. Otada su Jelica i Tone sjedjeli sami kao zaboravljeni od svih“ (CarEmin, 1912, 34-35). Čak se ni učitelj nije bavio njima, uvijek je obraćao pažnju samo na drugu, gradsku djecu koju je često gladio po licu i kosi. Govorio je samo

13 Majhut dobrotvora definira kao lik: „koji će siročetu pružiti i materijalna sredstva i toplinu, sigurnost i ljubav“"(Majhut, 2005, 213).

14 Govoreći o siročićima, Majhut navodi: „Nikako se ne smije posumnjati da je njihov društveni status rezultat karakternih nedostataka, da je njihovo stanje posljedica njihove pogreške. (...) roman o siročićima ima svoju društvenu dimenziju. Ta dimenzija se sastoji u prešutnoj pretpostavci sadržanoj u svakom romanu o siročiću o neophodnoj društvenoj, institucionalnoj brizi o djetetu." (Majhut, 2005, 181-182). 
talijanski, nije mu bilo bitno razumiju li ga Tone i Jelica. Kada je Tone pogriješio u izgovoru talijanske fraze učitelj se, umjesto da ga ispravi, smijao zajedno s drugim učenicima te nije zaustavio njihovo zadirkivanje. Car pripovijest završava plačem djece koja zbog negativnoga odnosa drugih prema njima, gube svaku vjeru u sebe.

\section{ZAKLJUČAK}

Viktor Car Emin čitav je svoj život i opus posvetio borbi protiv odnarođivanja hrvatske djece u Istri. Srdoč-Konestra (2008) navodi kako je, s obzirom na onodobne prilike, razumljiv Carev izbor za angažiranu književnost kao sredstvo u borbi protiv odnarođivanja. U tome djelovanju, značajno je Carevo pokretanje i uređivanje časopisa za mlade(ž) u kojima je i sâm pisao tekstove. Analiza njegovih odabranih tekstova pokazuje i dokazuje tipične motive i likove koje je Car stvaralački oblikovao pokušavajući i svojim mladim čitateljima približiti hrvatski narodni preporod u Istri. U crno-bijeloj podjeli likova (domaći su pozitivni, bijeli, a tuđinci negativni, crni), književna je estetika kod Cara padala u drugi plan, a u prvome je planu bilo prenijeti političku poruku.

Pišući o problemima koji su morili Istru, Car je žrtvovao svoju književnu karijeru. No, njegova žrtva nije bila uzaludna jer je svojim tekstovima pridonio hrvatskome narodnom preporodu u Istri obraćajući se najmlađima i najranjivijima - djeci. Generacije odgajane u jeku preporoda uvelike su imale koristi od čitanja Carevih djela jer su mnogi napuštali talijanske škole i prelazili u hrvatske ${ }^{15}$.

$15 \mathrm{O}$ tome nam najviše svjedoči činjenica da je časopis, na poticaj čitatelja (odnosno djece), promijenio ime u Mladi Hrvat kako bi se uočila distinkcija između općeistarskoga multikultur(al)nog i multinacionalnog mozaika (Hrvati, Slovenci, Talijani) i posebno, hrvatskoga stanovništva. Dakle, i Hrvati su narod u Istri koji zaslužuje sva prava na samobitnost, kulturu, prosvjetu, ekonomiju, opći razvoj, a ne samo Talijani ili neki drugi. Osvješćivanjem nacionalnoga identiteta došlo je do buđenja hrvatskoga naroda u Istri, što je rezultiralo odlučnošću u teškome poduhvatu da se otvaraju nove hrvatske škole te da se napuštaju tuđinske talijanske. 


\section{LITERATURA}

1. Car-Emin, V. (1909). I oni hoće da znadu. Mladi Istranin: list za mladi svijet. [Online] 1 (2): 28-29. Preuzeto 27. studenog 2019. sa: http://dnc.nsk.hr/journals/LibraryTitle.aspx?id=0d00748f-0a1549d2-96fa-2ed35a3835b9

2. Car-Emin, V. (1912). U tudjinskoj školi. Mladi Hrvat: list za mladi svijet. [Online] 4 (2): 34-35. Preuzeto 27. studenog 2019. sa: http://dnc.nsk.hr/journals/LibraryTitle.aspx?id=0d00748f-0a1549d2-96fa-2ed35a3835b9

3. Car Emin, V. (1949). Autobiografija. Zagreb: Nove borbe. U: B. Donat (prir.), Lujo Vojnović, Ante Dukić, Rikard Katalinić Jeretov, Niko Andrijašević, Viktor Car Emin - Izabrana djela. Pet stoljeća hrvatske književnosti, 1981 (588-617). Zagreb: Nakladni zavod Matice hrvatske.

4. Car Emin, V. (1953). Moje uspomene na „Družbu sv. Ćirila i Metoda za Istru“. Zagreb: Pedagoško književni zbor.

5. Cetnarowicz, A. (2014). Narodni preporod u Istri (1860-1907). Zagreb: Srednja Europa.

6. Demarin, M. (1978). Hrvatsko školstvo u Istri. Zagreb: Hrvatski školski muzej.

7. Donat, B. (1981). Viktor Car Emin. U: B. Donat (prir.), Lujo Vojnović, Ante Dukić, Rikard Katalinić Jeretov, Niko Andrijašević, Viktor Car Emin - Izabrana djela. Pet stoljeća hrvatske književnosti, 1981 (481-508). Zagreb: Nakladni zavod Matice hrvatske.

8. Lukežić, I. (2016). Viktor Car Emin - svjedok burnog vremena. U: B. Franković, M. Polić (ur.), Viktor Car Emin (1870. - 1963.): zbornik radova: povodom 145. obljetnice rođenja, 2016 (15-41). Mošćenička Draga: Katedra Čakavskoga sabora Općine Mošćenička Draga; Brseč: Udruga Jenio Sisolski.

9. Majhut, B. (2005). Pustolov, siroče i dječja družba: hrvatski dječji roman do 1945. Zagreb: FF press.

10. Milanović, B. (1973). Hrvatski narodni preporod u Istri. Knjiga II. Pazin: Istarsko književno društvo sv. Ćirila i Metoda u Pazinu.

11. Peruško, T. (1953). Pogovor. U: V. Car Emin, Moje uspomene na „Družbu sv. Ćirila i Metoda za Istru“, 1953 (117-139). Zagreb: Pedagoško književni zbor.

12. Radetić, E. (1969). Istarski zapisi. Zagreb: Grafički zavod Hrvatske.

13. Srdoč-Konestra, I. (2008). Književno djelo Viktora Cara Emina. Rijeka: Adamić.

14. Srdoč-Konestra, I. (2000). Ženski likovi u prozama V. Cara Emina. U: D. Stolac (ur.), Riječki filološki dani III, 2000 (407-416). Rijeka: Filozofski fakultet Sveučilišta u Rijeci.

15. Strčić, M. (1984). Istarska beseda i pobuna I. Pula: Istarska naklada.

16. Strčić, M. (1985). Istarska beseda i pobuna II. Pula: Istarska naklada.

17. Strčić, M. (1994). Temelji književne epohe: svećenici u hrvatskom narodnom preporodu Istre i kvarnerskih otoka. Pazin: Istarsko književno društvo "Juraj Dobrila". Rijeka: Novinskonakladničko poduzeće „Glosa“.

18. Šetić, N. (2005). O povezanosti Istre s ostalim hrvatskim zemljama - Naša sloga 1870.-1915. Zagreb: Dom i svijet.

19. Šetić, N. (2010). Staleška društva i časopisi hrvatskog učiteljstva u Istri 1891. -1914. Zagreb: Hrvatski književno-pedagoški zbor - Profil International.

20. Šetić, N. (2011). O periodičkom tisku za hrvatsku mladež u Istri početkom XX. stoljeća. Časopis za suvremenu povijest, 43(5): 249-263. Preuzeto 1. prosinca 2019. sa: https://hrcak.srce.hr/67523. 


\title{
ABOUT CROATIAN SCHOOL IN ISTRIA THROUGH JOURNALS OF VIKTOR GAR EMIN
}

\begin{abstract}
The literary work of Viktor Car Emin (1870-1963) is extensive and diverse and it includes texts and works written for children. This paper elaborates on Car's selected works from two Croatian magazines in Istria that he initiated and edited. Within this framework, two texts that present the problems of Croatian education in Istria are analyzed in this paper. The analysis shows that Car's literature for children was largely a product of the political situation in Istria at the begining of the $20^{\text {th }}$ century. His offering in the periodicals is proving to be patriotic and sentimental, didactic as well as nationalistic and political. Literary values were not of great importance to the author. On the contrary, political activism and rising of the awareness for one's national identity took the first place in his works. His works on education were a part of the political struggle for development of Croatian education in Istria as well as the author's address to young readers in their time and space.
\end{abstract}

Key words: Viktor Car Emin, children's literature, education, Croatian national revival in Istria, children's magazine 


\section{PRILOZI}

Prilog 1.: Naslovnica časopisa Mladi Hrvat

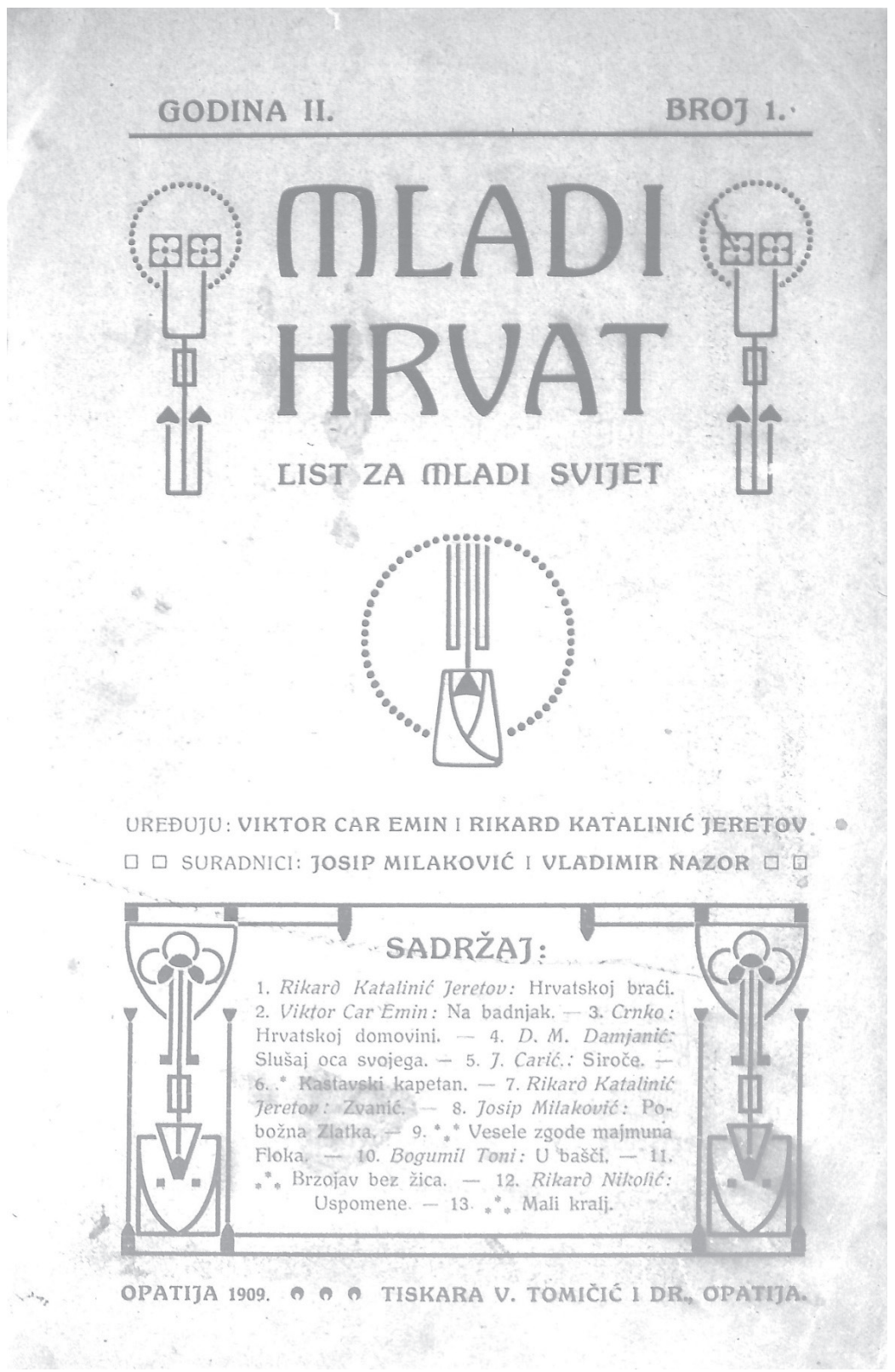

Izvor: http://dnc.nsk.hr/journals/LibraryTitle.aspx?id=0d00748f-0a15-49d2-96fa2ed35a3835b9 (Pristupljeno: 27. studenoga 2019.) 
Prilog 2.: Primjer Careve pripovijesti „Dogadjaj u malom zabitom selu“ iz Mladoga Hrvata

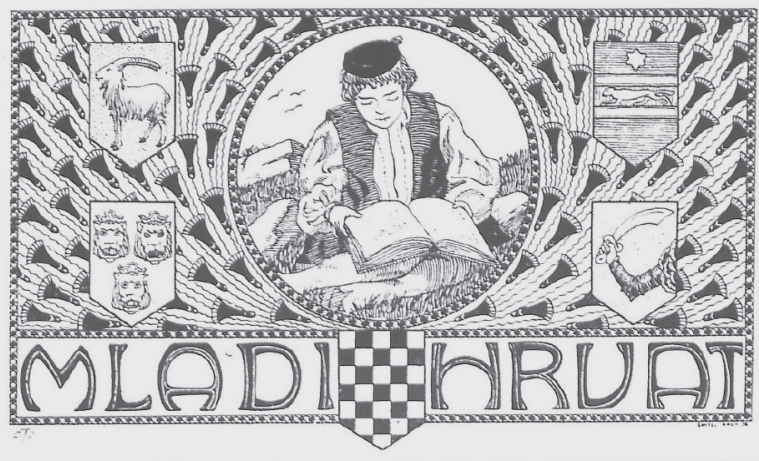

God. II. Opatija, 1. veljače $1910 . \quad$ Br. 2.

Dogadjaj u malom zabitnom selu.

I te kakav dogadaj! Prosudite: Stari Zaneto, listonoša iz grada, vanredno je rijedak gost u ovoj pustoši. Tri do četiri puta u godini prošepeljio bi kroz selo i naglo odlunjao dalje, a da se ne bi ni osvrnuo na taj kukauni svijet, što od nikud ne prima ni glasa ni pisma. Ali ni njega ne bi u selu poznavao nitko, da nije i za lijepa i za ružna vremena nosio nad glavom nekakav golemi platneni kišobran, na komu se prosulo stotinu i više zakrpa svakojake boje i veličine.

I danas, kad se ono odnekuda pomolio poznati kišobran, mislio svijet, da će Zaneto prosukati kroza selo, pa nikome ništa. Kad li onamo, naš čovjek ujedared stane nasred ceste i sve nešto kopa u svojoj velikoj torbi. U tinji se čas oko njega sleže čitavo selo kao na kakvo čudo. Nitko nije očekivao ni od kuda kakva glasa, ali je svima bilo milo, da mogu nešto iz bližega promatrati onaj ogromni šator nad Zanetovom glavom i ono njegovo obrijano, staračko lice.

Listonoša izuuče iz torbe maleni omot, pa će:

- Petar Tičić od Antuna!

Seljani se zgledaju. Tko bi to mogao biti? U selu ima već od davnine suaka kuća suoi poseban nadimak. Samo pre-

Izvor: http://dnc.nsk.hr/journals/LibraryTitle.aspx?id=0d00748f-0a15-49d2-96fa2ed35a3835b9 (Pristupljeno: 27. studenoga 2019.) 